\title{
A Brief Correspondence on Glyphosate Remediation using Microbes and Mineral Sources
}

\author{
Bisma Imran $\mathrm{Ch}^{1}$, Aqarab Husnain Gondal ${ }^{1 *}$, Hooria Zafar ${ }^{1}$, Hasnain Umar ${ }^{2}$, Muhammad Danish Toor ${ }^{3}$, Asma \\ Zafar $^{1}$, Qammar Farooq ${ }^{1}$ and Saba Saeed ${ }^{1}$
}

${ }^{1}$ Institute of Soil and Environmental Sciences, University of Agriculture, Pakistan

${ }^{2}$ Department of Agronomy, University of Agriculture, Pakistan

${ }^{3}$ European University of Lefke, Institute of Graduate Studies and Research, Department of Environmental Sciences Northern Cyprus TR-10 Mersin Turkey

Submission: May 11, 2021; Published: May 20, 2021

"Corresponding author: Aqarab Husnain Gondal, Institute of Soil and Environmental Sciences, University of Agriculture, Pakistan

\begin{abstract}
Glyphosate is a non-selective herbicide used to control a large variety of annual and perennial weeds. Its pervasive use, however, has harmful implications for living things and the environment. Aside from that, it affects aquatic ecosystems and soil microbial biota, resulting in a loss of soil fertility and, therefore, reduced plant growth and production, all of which has an effect on the food chain. Various techniques have been used to exclude glyphosate from contaminated habitats, but microbial depletion and the use of nitrogen, phosphorus, and plant growth regulators, as well as the use of glyphosate resistant crops, either singly or in combination, are the most environmentally sustainable and cost-effective options. Microbes release basic elements in the soil by their enzymatic processes, and they play an important role in improving plant growth and phytoremediation capacity by lowering the total toxicity of a pollutant to plants. Furthermore, dehydrogenase and urease processes, which are known to be the most critical measures of overall microbial development, are greatly influenced by nitrogen and phosphate fertilizers. In addition, plant growth regulators improve the glyphosate contaminated soil as well. The present review discusses the glyphosate effects and its possible solution in terms of organic and inorganic amendments.
\end{abstract}

Keyword: Glyphosate polluted soils; Growth regulators; Microbes; Glyphosate resistant crops; Yield

Abbreviations: Ops: Organochlorine Pesticides; HCHs: Hexachlorocyclohexane; GR: Genetically Resistant; PGPB: Plant Growth-Promoting Rhizobacteria; EPA: Environmental Protection Agency; PGRs: Plant Growth Regulators

\section{Introduction}

Organochlorine pesticides (OPs) are synthetic chlorinated hydrocarbon pesticides that are widely used as pesticides that are stable throughout nature Aktar [1]. Hexachlorocyclohexane (HCHs) is an OP formed when the benzene ring is chlorinated in the presence of light Metcalf. Glyphosate is an OP that is used to manage numerous seasonal and annual weeds in domestic gardens, farmlands, and aquatic systems. It is a post-emergence, broad-spectrum, non-selective herbicide Walpola [2]. Algal blooms and noxious underwater plants are also managed with glyphosate Siemering [3]. Furthermore, the widespread use of glyphosate in cultivation has increased after the introduction of genetically resistant (GR) crops such as maize, canola, sugar beet, and soybean Woodburn. Glyphosate is used in agriculture and has the potential to increase maize yield by $19 \%$ Masthan. Without pesticides, the overall reduction of crop production due to algae, rodents, and other diseases doubles FAO [4]. In previous years, glyphosate was more often used than other OPs Lipok et al.

The use of glyphosate on a regular basis has a negative impact on the environment and human health. Glyphosate is stable in soil and the atmosphere after treatment Ellis \& Griffin [5]; Wang et al. The half-life of glyphosate in soil may be as long as 174 days Vencill [6]. Its excessive use of soil pollutes water and food, and it's been linked to cancer and mutation. Increased glyphosate uptake and concentration of consumable parts of the crop has a detrimental impact on human wellbeing, causing tumours in every portion of the human body (prostate, lungs, and liver), as well as disrupting the nervous system and animal reproduction $\mathrm{Xu}$ et al. [7]. Furthermore, most OPs, including glyphosate, are mobile in nature and causing groundwater pollution. The Figure 1 demonstrates the glyphosate effects on different systems. Various 
strategies are used to remove glyphosate from the contaminated environments and mitigate the effect of glyphosate on the soilplant system. Among all methods use of glyphosate resistant crops with higher application of nitrogen and phosphorus than normal dosages, use of microbes, and plant growth regulators could be suitable option to mitigate the above-mentioned problems.

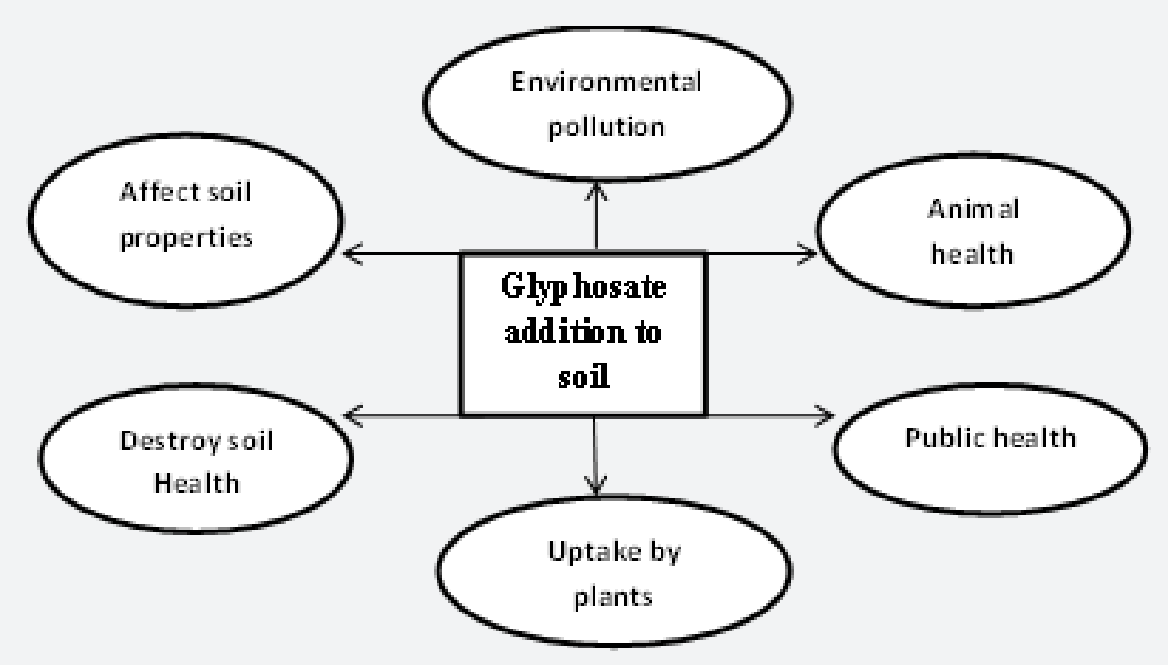

Figure 1: Glyphosate effects on whole ecosystems including environment.

HCHs can be degraded by microorganisms and used as a fossil source. Microbes convert contaminants into less toxic substances, which help to clean up the dirt and water Maheshwari et al. In agricultural soil, plant growth-promoting rhizobacteria (PGPB) are used as inoculants to improve soil fertility. Bacterial inoculation promotes plant growth by lowering the expense of chemical fertilisers. The efficacy of inoculants is influenced by a number of factors, including root exudates, bacterial root colonization, and soil quality Rocheli et al. Bacterial inoculation improves water use quality, photosynthesis rate, and stomatal conductance, as well as plant water content Vivas et al. Rhizobium that fixes nitrogen may degrade toxic compounds into nontoxic forms Shivaramaiah \& Kennedy. Rhizobium developed enzymatic action to detoxify contaminants as a result of increased pollutant exposure Zinjarde et al. They also influence the macro and micro especially (Zn) nutrient availability up to extent which can take part in many enzymes' activation Gondal et al. [8]; Bakar Ijaz et al. [9]; Gondal et al. [10]. Rhizofiltration, Plant extraction, plant stabilization, plant evaporation and plant decomposition, and rhizosphere degradation are some of the main processes involved in phytoremediation. Using chelating and acidifying agents, adding electric current to the soil, using organic chemicals and fertilizers, planting transgenic seeds, using bacteria, and using plant growth regulators will all improve the effectiveness of phytoremediation.

Plant growth regulators (PGRs) play a critical role in plant production and growth. PGRs are described by the US Environmental Protection Agency (EPA) as any compound that increases or decreases plant growth by altering biological processes Hopkins; Fishel. Plant development is aided by PGRs, which reduce the harmful effects of toxins in the soil. Auxin is one of the most critical PGRs of all the PGRs Frankenberger \& Arshad. Plant growth regulators have recently been studied as a viable tool for enhancing phytoremediation efficacy. The gibberellins, auxins, and salicylic acid are effective plant growth regulators for phytoremediation. These materials' behaviour is determined by their concentration, environmental factors that influence absorption, and the physiological condition of the plant. Nitrogen is one of the most essential elements for plant growth Stefanovic [11]. Glyphosate application with nitrogen fertilizer is increased worldwide in order to mitigate the negative impacts of pollutants such as glyphosate on environment and growth of plants Nivelle et al. [12]. The metabolic activities such as nutrients availability, nitrate contents, phosphate contents, alkaline phosphatase and urease enzymes activities and nitrification process are enhanced after application of glyphosate with nitrogen fertilizer Nivelle et al. [12]. In addition, nitrogen fertilizers significantly influence the dehydrogenase and urease activities, which are considered as most important indicators of total microbial activity Dick et al. [13]. In general, microbes use two pathways to decompose the glyphosate compound namely glyoxylate and aminomethylphosphonic acid Schuette [14].

The presence of phosphate greatly reduced glyphosate adsorption to soils by vying with glyphosate for soil adsorption locations. Meanwhile, on the two transient charge soils, the effects of phosphate on glyphosate adsorption were more important than on the permanent charge soil. Previous studies revealed significantly enhancement in crop growth and yield due to application of phosphorus in glyphosate contaminated soils Wang et al. [15]. As phosphate and glyphosate were applied to the soils in various orders, the adsorption concentrations of glyphosate 
on the soils varied, as follows: GPS-soil > GPS-P-soil = GPS-soil-P $>$ P-soil-GPS, implying that glyphosate, phosphate, and the soils had a complex relationship Wang et al. [15]. Using these products raises the plant's biomass while reducing the harmful effects of toxins in the environment. Phosphorus is an important nutrient because it is more concerned with the plant metabolism and energy transfer process Marschner [16]. Glyphosate inhibits the shikmate pathway and negatively effects on photosynthesis process Siehl \& Roe [17]. As phosphate and glyphosate compete for adsorption sites in the soil so, it can be uptake by the plant Denis \& Delrot [18]. Glyphosate can uptake and translocate in soil and can remediate soil through phytoremediation. Available phosphorus can enhance the physiochemical properties of plants. Gomes et al. [19] concluded that willow plant phytoremediation increase by the addition of mineral nutrient Gomes et al. [19].

When opposed to hand weeding, industrial glyphosate formulations and pure active ingredients will decrease earthworm development, with cascading effects on glyphosate fate in soil and leachate. We propose that associations between formulations and active ingredients exist because water penetration and glyphosate in soil and water were both interactively mediated by soil properties. A full disclosure of all ingredients in the formulations will be needed to properly understand the differential effects of formulations vs. their active ingredients. More research into long-term effects at various trophic levels appears to be needed for a more realistic assessment of the ecological side effects of glyphosate herbicides [20-22].

\section{Conclusion}

In conclusion, Pakistan imports a substantial volume of pesticides per year, including herbicides, insecticides, and fungicides. It is undeniable that improper and inappropriate application of pesticides, especially glyphosate, has adverse effects on human health and the climate, while determining the true nature of these effects is challenging. Several scientists use various approaches to remove glyphosate and mitigate its toxic effects on plants; however, limited studies are available on the use of microbes in combination with different level of $\mathrm{N}$ and $\mathrm{P}$ fertilizers for improving growth and removal of glyphosate from soil. Therefore, the aim of this study is to evaluate the effects of a microbial consortium and different level of nitrogen on remediation of glyphosate and growth of maize in glyphosatepolluted soil. It is important to encourage organic farming activities that use bio-pesticides or biological agents to combat weeds rather than herbicides to minimize the use of glyphosate.

\section{References}

1. Aktar W, Sengupta D, Chowdhury A (2009) Impact of pesticide use in agriculture and their benefits and hazards. Interdiscip Toxicol 2(1): $1-12$.

2. Walpola DC, Wanniarachchi SD, Liyanage LA (2007) Responses of soil microbial biomass carbon to the herbicides propanil and glyphosate. Journal Agricultural Sciences 3: 122-130.
3. Siemering GS, Hayworth JD, Greenfield BK (2008) Assessment of potential aquatic herbicide impacts in California aquatic ecosystems. Archives of Environmental Contamination and Toxicology 55(3): 415431.

4. (2017) FAO. Trade and market division, food outlook: oilseeds. Oils and Meals, pp. 1-16.

5. Ellis JM, Griffin JL (2002) Soybean and cotton response to simulated drift of glyphosate and glufosinate. Weed Technology 16: 580-586.

6. Vencill WK (2002) Herbicide handbook ( $8^{\text {th }}$ edn). Weed Science Society of America.

7. Xu J, Smith S, Smith G, Wang W, Li Y, et al. (2019) Glyphosate contamination in grains and foods. Food Control, p. 106.

8. Gondal AH, Zafar A, Zainab D, Toor MD, Sohail S, et al. (2021a) A Detailed Review Study of Zinc Involvement in Animal, Plant and Human Nutrition. Ind J Pure App Biosci 9(2): 262-271.

9. Bakar Ijaz SS, Bisma Imran $\mathrm{CH}$, Taufiq Nawaz S, Haider IAA, Dua-eZainab BR, et al. (2021) Alleviation of zinc deficiency from humans through plants by organic sources: A Powerful Tonic. IJAR 7(4): 240243.

10. Gondal HA, Sohail H, Niazi DM, Touseef H, Khan M, et al. (2021b) Influence of Soil $\mathrm{Ph}$ and Microbes on Mineral Solubility and Plant Nutrition: A Review. International Journal of Agriculture and Biological Sciences 5(1): 71-81.

11. Stefanovic I, Prokic S, Rankovic L (2010) Motivational and success factors of entrepreneurs: the evidence from a developing country. Proceeding of the Faculty of Economics in Rijeka 28(2): 251-269.

12. Nivelle E, Verzeaux J, Chabot A, Roger D, Spicher F, et al. (2017) Does nitrogen fertilization history affects short-term microbial responses and chemical properties of soils submitted to different glyphosate concentrations? PLOS ONE 12(5): e0178342.

13. Dick WA, Tabatabai MA (1992) Significance and potential use of soil enzymes. A meeting on soil microbial ecology and application and environmental management. Marcel Dekker, New York, USA, pp. 99110.

14. Schuette J (1988) Environmental fate of glyphosate. Environmental Monitoring and Pest Management 1(1): 1-13.

15. Wang YJ, Zhou DM, Sun RJ (2005) Effects of phosphate on the adsorption of glyphosate on three different types of Chinese soils. Journal of Environmental Sciences 17(5): 711-715.

16. Marschner H (1995) Mineral nutrition of higher plants. ( $2^{\text {nd }}$ edn). Academic Pres.

17. Siehl DL, Roe RM (1997) Inhibitors of EPSP synthase, glutamine synthetase and histidine synthesis. Reviews in Toxicology 1: 37-68.

18. Denis MH, Delrot S (1993) Carrier-mediated uptake of glyphosate in broad bean (Vicia faba) via a phosphate transporter. Physiologia Plantarum 87(4): 569-575.

19. Gomes MP, Le Manac'h SG, Moingt M, Smedbol E, Paquet S, et al. (2016) Impact of phosphate on glyphosate uptake and toxicity in willow. Journal of hazardous materials 304: 269-279.

20. Lipok J, Wieczorek D, Jewgin MS, Kafarski P (2009) Prospects of in vivo 31P NMR method in glyphosate degradation studies in whole cell system. Enzyme and Microbial Technology 44(1): 11-16.

21. Arshad M, Frankenberger WT (1991) Microbial production of plant hormones. The Rhizosphere and Plant Growth, pp. 327-334.

22. Morin F, Vera V, Nurit F, Tissut M, Marigo G (1997) Glyphosate Uptake inCatharanthus roseusCells: Role of a Phosphate Transporter. Pesticide Biochemistry and Physiology 58(1): 13-22. 


\section{Your next submission with Juniper Publishers} will reach you the below assets

- Quality Editorial service

- Swift Peer Review

- Reprints availability

- E-prints Service

- Manuscript Podcast for convenient understanding

- Global attainment for your research

- Manuscript accessibility in different formats ( Pdf, E-pub, Full Text, Audio)

- Unceasing customer service

Track the below URL for one-step submission https://juniperpublishers.com/online-submission.php 